\title{
Psikolojik Sözleşme Algısının İşe Adanmışlık Üzerindeki Etkisi
}

\author{
Engin KANBUR \\ Kastamonu Üniversitesi Sivil Havacılık Yüksekokulu Havacılık Yönetimi Bölümü \\ ekanbur@kastamonu.edu.tr \\ ORCID ID: https://orcid.org/0000-0002-6261-9314
}

Ali AY

Kastamonu Üniversitesi Sosyal Bilimler Enstitüsü İşletme

aay@ kastamonu.edu.tr

ORCID ID: https://orcid.org/0000-0002-6261-9314

\begin{tabular}{lrr} 
Araştırma Makalesi & DOI: 10.31592 aeusbed.615587 \\
\hline Geliş Tarihi: 04.08 .2019 & Revize Tarihi: 11.05 .2020 & Kabul Tarihi: 13.05 .2020
\end{tabular}

\author{
Atıf Bilgisi \\ Kanbur, E. ve Ay, A. (2020). Psikolojik sözleşme algısının işe adanmışlık üzerindeki etkisi. Ahi Evran \\ Üniversitesi Sosyal Bilimler Enstitüsü Dergisi, 6(2), 531-549.
}

\section{ÖZ}

Kurumlar, en değerli kaynağı olan çalışanlarının iş tatminlerini ve örgütlerine olan bağlılıklarını arttırmak için, çalışanlar ile güvene dayalı bir ilişki kurmaya zemin hazırlayan psikolojik sözleşme uygulamalarına önem vermeye başlamışlardır. Bu araştırmanın temel amacı, çalışanların psikolojik sözleşme algılarının işe adanmışlık davranışları üzerindeki etkisinin incelenmesidir. $\mathrm{Bu}$ amaç kapsamında araştırma verileri, Kastamonu Üniversitesi idari personeli olarak görev yapan 250 çalışandan anket tekniği ile toplanmıştır. Araştırma verileri korelasyon analizi ve çoklu regresyon analizi ile test edilmiştir. Araştırma bulgularına göre, çalışanların psikolojik sözleşme algılarının ve alt boyutlarından biri olarak ilişkisel psikolojik sözleşmenin işe adanmışlık davranışları üzerinde pozitif ve anlamlı bir etkiye sahip olduğu görülmektedir. Ayrıca, psikolojik sözleşme algısının alt boyutlarından işlemsel psikolojik sözleşme boyutu işe adanmışlık boyutlarından yoğunlaşma boyutu üzerinde pozitif ve anlamlı bir etkiye sahip iken ilişkisel psikolojik sözleşme boyutunun ise dinçlik ve adanmışlık boyutları üzerinde pozitif ve anlamlı bir etkiye sahip olduğu vurgulanmaktadır. Psikolojik sözleşme algısı ve işe adanmışlık arasındaki ilişkilerin analiz edilmesi ile teoriye ve uygulamaya önemli katkılar sağlanacağı düşünülmektedir.

Anahtar Kelimeler: Psikolojik sözleşme algısı, işe adanmışlık, dinçlik, yoğunlaşma, adanmışlık.

\section{The Effect of Psychological Contract Perception on Work Engagement}

\begin{abstract}
In order to increase job satisfaction and loyalty of their employees, which are their most valuable resource, corporations have begun to give importance to the psychological contract practices that lay the ground for establishing a trust based relationship with employees. The main purpose of this study is to examine the effects of psychological contract perceptions of the employees on their work engagement. In this context, data of the research were collected from 250 employees who are working as administrative staff in Kastamonu University. Data of the research were tested by correlation analysis and multiple regression analysis. According to the findings of the study, it can be seen that psychological contract perceptions of the employees and relational psychological contract as one of its subdimensions have a positive and significant effect on work engagement behaviors. In addition, it is emphasized that transactional psychological contract dimension, which is one of the subdimensions of psychological contract perception, has a positive and significant effect on absorption as one of the dimensions of work engagement whereas relational psychological contract dimension has a positive and significant effect on vigor and dedication. By analyzing the relationships between psychological contract perception and work engagement, it is thought that important contributions will be made to the theory and practice.
\end{abstract}

Keywords: Psychological contract perception, work engagement, vigor, absorption, dedication

\section{Giriş}

Günümüzde kurumların ve çalışanların geliştirmiş oldukları ilişkinin niteliğini ortaya koyan ve tarafların yükümlü oldukları sorumlulukları düzenleyen biçimsel sözleşmeler tarafların yazılı olarak dile getiremedikleri beklentilerini ve inançlarını yansıtamadığı için yetersiz kalmaktadır. Çünkü çalışanlar istihdam edildikleri yerlerdeki yazılı düzenlemelerin yanı sıra kendi içlerinde birtakım 
beklentilere sahip olabilmekte ve bunu çoğu zaman dile getirmemektedirler. Bu beklentilerin karşılanması çalışan ile kurum arasında güvene dayalı bir ilişkinin sürdürülmesine ve çalışanın kendini kuruma adamasına neden olabilmektedir. Ancak karşılıklı beklentilerin karşılanmaması durumu kuruma olan güveni azaltmakta ve çalışanların kuruma olan adanmışlıklarını engelleyebilmektedir.

Küreselleşme, teknolojik gelişmeler ve yoğun rekabet gibi nedenlerden dolayı kurumlar çalışanlarının performansını arttırmak için onların davranışlarını anlamaya, iş tatminlerini ve örgütsel bağlılıklarını artırmaya çalışmaktadırlar. Bu yeni süreçte ve yaşanan örgütsel değişimler nedeniyle çalışma ilişkilerini düzenleyen ve ortaya çıkan değişimlere birer araç niteliği taşıyan çeşitli kavramlar ortaya çıkmıştır. Bu kavramlardan psikolojik sözleşme algısı ve işe adanmışlık kavramları son yıllarda hem özel sektörde hem de devlet kurumlarında önemli bir yer tutmaya başlamıştır. Kurumlar, çalışanların iş tatminlerini ve örgütlerine olan bağlılıklarını arttırmak için, çalışanlarıyla güvene dayalı bir ilişki kurmasına ve çalışanın kuruma kendini adamasına zemin hazırlayan psikolojik sözleşme uygulamalarına önem vermeye başlamışlardır.

$\mathrm{Bu}$ araştırmanın odak noktası psikolojik sözleşme algısının bir sonucu olan işe adanmışlık düzeyidir. $\mathrm{Bu}$ çerçevede psikolojik sözleşme ve işe adanmışlık düzeyi arasındaki ilişkiler araştırılmaktadır. Bu bağlamda araştırmanın amacı, Kastamonu Üniversitesi'nde vazife yapan idari personelin psikolojik sözleşme algılarının işe adanmışlık düzeyleri üzerindeki etkisini belirlemektir. Kastamonu Üniversitesi'nde gerçekleştirilen bu çalışmanın temel katkısı, ülkemizdeki özel sektör işletmelerinde olduğu kadar kamu kurumlarında da önem kazanan psikolojik sözleşme ve işe adanmışlık kavramlarını bütüncül bir model çerçevesinde ele alarak literatüre zenginlik kazandırmaktır. İkinci katkısı, bilgi çağında birer öğrenen örgüt olma yolunda çabalar gösteren üniversitelerdeki idari personelin durumunu ortaya koymaktır.

\section{Psikolojik Sözleşme Algısı}

Psikolojik sözleşme kavramının ortaya çıkışı Argyris tarafından 1960 yılında gerçekleştirilen çalışmaya dayanmaktadır. Argyris (1960), psikolojik sözleşme kavramını ilk defa, çalışanlar ile işverenler arasındaki ilişkileri tanımlamak amacıyla kullanmış ve bu kavramı örgüt içerisinde yüksek üretim sağlamak ve sorunları en aza indirgeyebilmek adına; yazılı olmayan, iki taraflı bir sözleşme şeklinde tanımlamışıır. Levinson, Price, Munden, Mandl ve Solley (1962) ise kavrama netlik kazandırarak "örgüt ve bireyin birbirlerinden karşılıklı ve yazılı bir dayanağı bulunmayan beklentilerinin toplamı" şeklinde ifade etmişlerdir (Tuzlukaya ve Kırkbeşoğlu, 2015). Rousseau (1989) ise psikolojik sözleşmeye ilişkin karşıllklılık algısını birey seviyesine indirgeyerek çalışanların işle alakalı ilişkileri kapsamındaki karşılıklı yükümlülüklere dair algı ve beklentileri olarak ifade etmiştir. Ayrıca Rousseau (1995) psikolojik sözleşme kavramına, örgüt ile bireyler arasındaki mübadele çerçevesinde örgüt tarafından şekillendirilmekte olan bireysel inançlar şeklinde de bir tanım getirmiştir. Schein (1980) psikolojik sözleşme kavramını insan kaynakları uygulamaları açısından ele alarak aynı örgüt içerisindekilerin kendi aralarında varlı̆̆ını koruyan yazılı olmayan beklentilerinden bahsetmiş, örgüt ile birey seviyesinde ayrı ayrı saptamalarda bulunmuştur (Topcu, 2015).

Psikolojik sözleşme kavramı, örgütsel çevrede yaşanan hızlı değişim ve gelişimler neticesinde meydana gelen, istihdam ilişkileri ve modern iş hayatını anlayabilmek amacıyla kullanılabilecek bütünleştirici bir kavram olarak ele alınmaktadır (Anderson ve Schalk, 1998; Shore ve Tetrick, 1994; Turnley ve Feldman, 2000). Resmi bir sözleşmeye göre daha öznel, beklentilerin ötesinde geniş kapsamlı bir kavram olan psikolojik sözleşme, karşılıklı bir şekilde çalışanlar ile örgütlerin birbirlerinden ne umduklarını ve başarı ya da başarısızlıklarının neticelerini ortaya çıkaran, açıkça dile getirilmemiş bir anlaşmadır (Cihangiroğlu ve Şahin, 2010). Psikolojik sözleşme ana hatlarıyla işveren ve çalışan arasında olan karşılıklı zorunluluklar ile alakalı inanç ve algıların tümü ve istihdam ilişkisinin temeli şeklinde tanımlanmaktadır. Söz konusu olan karşılıklı zorunluluklar, hem çalışanların işverene, hem de işverenin çalışanlara karşı yükümlülüklerini içermektedir (Conway ve Briner, 2005).

Psikolojik sözleşmeler, istihdam ilişkisinin daha kapsamlı incelenmesine ve örgüt içerisinde varlığını koruyan ancak açıkça ortaya konulamayan anlaşmalara yoğunlaşılmasına olanak 
sağlamaktadır (Guest, 2004). Psikolojik sözleşme kişiseldir yani işveren ya da çalışanın karşıllıklı algısına bağlıdır (Tarakcı ve Akın, 2017). Psikolojik sözleşme, birçok araştırmacı tarafından özenle incelenen bir konu olmakla birlikte üzerinde bir fikir birliğine varılamamıştır (Büyükyılmaz ve Çakmak, 2014). Konuyla alakalı farklı y1llarda öne sürülmüş olan görüşler incelendiğinde, psikolojik sözleşmenin; beklentiler, algılar, inançlar, taahhütler ve yükümlülüklerin toplamını ifade eden bir kavram olduğu sonucuna varılmaktadır (Üçok ve Torun, 2014). Psikolojik sözleşme, çalışanın örgüt ile olan ilişkisi açısından önemli bir kavram olduğu için istihdam ilişkisi kapsamında devamlı karşılaşılan bir durum olduğu ifade edilmektedir (Büyükyılmaz ve Çakmak, 2014). Örgütler tarafından çalışana verilmiş olan taahhütlerin yerine getirilmesinde zorlanılması veya çalışanlar tarafindan beklenilenin dışında taahhütlerin yerine getirilmeyişi, çalışanların örgüte karşı yükümlülüklerine ilişkin bir düşüşe sebep olmaktadır (Aselage ve Eisenberger, 2003).

Psikolojik sözleşmeler, “ilişkisel” ve "işlemsel” olarak iki ayrı kategori altında incelenmektedir (Macneil, 1985). Macneil (1985), işlemsel sözleşmeyi belli bir süre içerisinde taraflar arasında oluşan belli parasal değişimler şeklinde ifade ederken aralarındaki ilişkisel sözleşmeyi ise, ilişkileri kuran ve koruyan, daha belirsiz ve değişebilen anlaşma şeklinde ifade etmiştir (Cihangiroğlu ve Şahin, 2010). İşlemsel sözleşme; sözleşmelerin ekonomik boyutuna yönelmekte iken, adil bir çalışma sonucu hak edilen ücretin adil olmasına odaklanmaktadır (Rousseau ve Wade-Benzoni, 1994). İşlemsel sözleşme, maddesel düşünceyi temel almakta ve tarafların katılımının kısıtlı olduğu görüşüne dayanmaktadır (Topcu, 2015). İlişkisel sözleşme; hem çalışan hem de işveren açısından, açık uçlu tüm süreci kapsayan önemli bir araç şeklinde görülmektedir (Rousseau ve Wade-Benzoni, 1994). Bu tür sözleşmeler örgütsel vatandaşlık davranışı ile alakalıdır. Çalışanlar maddi korkulardan uzak bir şekilde tamamıyla kurumlarına dair hissi bağları sebebiyle istekli olarak örgütsel vatandaşlık davranış1 göstermektedirler (Ertürk, 2014). İlişkisel psikolojik sözleşmede personelden örgüte sadık olması, fazla mesai yapması ve ekstra-rol davranışı sergilemesi istenmekte, işveren tarafından ise çalışana daimî bir işi olacağına dair güvence, eğitim, kişisel sorunlarda destek ve kariyer geliştirme imkânları sunması beklenmektedir. İlişkisel sözleşme taraflarda karşılıklı saygınlık algısı oluşturmaktadır (Purvis ve Cropley, 2003).

\section{İşe Adanmışlık}

Örgütlerin rekabette üstünlük kazanmasını ve bu üstünlüğü devam ettirmesini sağlayan en önemli unsur insan kaynağıdır (Gafa ve Dikmenli, 2019). Bu kaynağın psikolojik ve sosyal yönünün ele alınıp incelenmesinde ve örgüt amaçları için etkin ve verimli kullanılmasında örgütsel davranış disiplininin kritik öneme sahip olduğu vurgulanmaktadır. Dolayısıyla pozitif örgütsel davranış çerçevesinde incelenen konulardan biri olan işe adanmışlık, örgütün başarı sağlamasında ve bunu sürdürmesinde çok önemlidir (Yavan, 2016). İşe adanmışl1k, örgütsel yaşam kapsamında örgüt adına birçok faydalı çıktıya olanak sağlayarak, olumlu iş tecrübelerini temsil etmektedir (Yakın ve Erdil, 2012). Günümüz örgütlerinde çalışanların, diğerlerinden daha üstün performans sergilemeleri, inisiyatif almaları, proaktif davranışlar sergilemeleri ve öğrenme isteklerinin diğerlerine göre daha yüksek olması işe adanmışlıkla açıklanmaktadır (Bostancı ve Ekiyor, 2015).

İşe adanmışlığ literatüre kazandıran ilk kişi ve işe adanmışlık konusunda literatürde kullanılan en yaygın tanımın sahibi Kahn (1990) olarak kabul edilmektedir (Bakker, 2011). Bu tanıma göre işe adanmışlık; personelin hem fiziki olarak hem fikirsel olarak hem de hissi olarak tam anlamıyla kendilerini yaptıkları işe adamaları olarak tanımlanmaktadır (Kahn, 1990). Uluslararası literatürde "job-work-employee-organizational engagement" olarak belirtilen kavram Türkçe çalışmalarda işe bağlanma, işe cezbolma, işle bütünleşme, işe adanma, işe gönülden adanma ve işe adanmışlık gibi değişik şekillerde ifade edilmektedir (Terlemez, 2012).

İşe adanmışlık literatür çerçevesinde ele alındığında, kavrama ilişkin farklı birçok tanımlama olduğu görülmektedir. Robert ve Davenport (2002) işe adanmışlı̆̆ı bireyin işi ile ilgili bağlılık duyması ve coşku hissetmesi olarak ifade etmektedir. Catsouphes ve Costa (2009) da işe adanmışlığı iş ile ilgili pozitif, heyecan verici ve duygusal bir ilişki olarak tanımlanmaktadır (Catsouphes ve Costa, 2009). İşe adanmışlık Maslach vd.'ne (2001) göre dâhil olma, enerji ve yeterlilikle karakterize 
edilmektedir (Maslach, Schaufeli ve Leiter, 2001). Çalışanın iş ile bütünleşmesi olarak belirtilen işe adanmışlık, çalışanların iş rollerine ilişkin besledikleri olumlu hisler, tutkular, motive edici davranışlar ve devamlılık içeren zihinsel bir süreç şeklinde ifade edilmektedir (Schaufeli, Salanova, GonzalezRoma ve Bakker, 2002). Buna ek olarak Gonzalez-Roma, Schaufeli, Bakker ve Lloret (2006) göre de kendini adama ve zindelik işe adanmışlı̆̆ın diğer iki özelliğidir (Özyılmaz ve Süner, 2015). Schaufeli ve Bakker (2004) işe adanmışlık kavramını, çalışanın azimli yönüyle ilişkili olumlu bir durum olarak belirtmektedir (Schaufeli ve Bakker, 2004). May, Gilson ve Harter (2004) ise Kahn'ın (1990) işe adanmışlık üzerine yaptığı tanımı destekleyerek, işe adanmışlık kavramını çalışanın üstlendiği rolde performans gösterirken kendisini fiziksel, bilişsel ve duygusal olarak o rolde tanımlaması şeklinde ifade etmektedirler (May, Gilson ve Harter, 2004; Yener, 2019; Yener ve Demirtaş, 2018).

İşe adanmışlığı olumlu ve çalışanın azimli yönüyle ilgili bir durum olarak ifade eden Schaufeli ve Bakker (2004), bu kavramı dinçlik, yoğunlaşma ve adanmışlık boyutları ile özdeşleştirerek açıklamışlardır (Sarıkaya, 2016). Dinçlik; kişinin işte çalışırken sarf edeceği üst düzeyde gösterilen enerji miktarını ve güçlü bir kimliği ifade etmektedir. Ayrıca yılgınlığın karşıtı bir karakterdedir (Schaufeli ve Bakker, 2004). Antonison (2010) dinçliği, çalışanın yüksek düzeyde enerjiye sahip olması, sahip olduğu enerjiyi iş için harcama isteği duyması ve karşılaşılan zor koşullara dayanması şeklinde ifade etmiştir (Antonison, 2010). Literatürde çalışanların dinç bir yapıya sahip olmalarının; esnek ve yaratıcı düşünebilmelerinin geliştirilmesi, performanslarının artması, etkili karar verebilmeleri, prososyal davranmaları gibi bireysel ve örgütsel bazı yararları olduğu ileri sürülmektedir (Shraga ve Shirom, 2009). Yoğunlaşma kavramını ilk defa kullanan Goffman (1959) kişinin üstlendiği role yoğunlaşması ve kendini ve tüm enerjisini bu role vermesi olarak tanımlamış, bunun yapılan işe görünür bir bağll1ık ve aktif bir şekilde adanma olarak kendini gösterdiğini söylemiştir (Bal, 2008). Antonison (2010) yoğunlaşmayı, çalışanın işe yüksek düzeyde ilgi duyması, işinden dolayı gurur duyması ve yüksek düzeyde sorumluluk üstlenmesi şeklinde ifade etmiştir (Antonison, 2010). Deese (2009) ise yoğunlaşma, çalışanın kendi değerleri ile işin uyumunu veya kendi değerlerine göre işinin önemli olduğunu içselleştirmesi olarak tanımlanmaktadır (Deese, 2009). İşe adanmış olan çalışanların aynı zamanda işlerine yoğunlaşmaları ile mümkündür (Kanten, 2012). Adanmışlı ise, çalışanların beceri ve motivasyonlarını ortaya çıkararak, en iyi performansı meydana çıkarma hedefi için fonksiyonel olan bir 'bilinç' durumuna işaret etmektedir. Adanmışlık, tükenmişlik (burnout) ve ilgisizlik kavramları ile karakteristik olarak zit yönde bir kavramdır (Öner, 2007). Antonison (2010) adanmışlı̆̆ı, çalışanın işe konsantre olması, iş yerinde zamanın çabuk geçtiğini düşünmesi ve işi bırakmak istememesi şeklinde ifade etmiştir (Antonison, 2010). Kendini adamış çalışanlar, kendi istekleriyle iş süreçlerinin tamamında yer almaktadırlar (Rich, 2006). Örgütlerine güvenen ve çalışma ekibi tarafından destek verilen örgüt çalışanları, kendilerini işlerine daha çok adamaktadirlar (Chughtai ve Buckler, 2008).

\section{Kuramsal Altyapı ve Hipotez Geliştirme}

Psikolojik sözleşme ve işe adanmışlık ile ilgili yapılan tanımlamaların tamamında, işveren ile çalışan arasında bir ilişki mübadelesi ve sonuçları bulunmaktadır. Dolayısıyla bu karşılıklılık, psikolojik sözleşme ve işe adanmışlık kavramlarına ilişkin en temel açıklayıcı kuramsal unsurdur. Psikolojik sözleşmeye yönelik araştırmaların temelini, işverenin davranışları neticesinde çalışanın nasıl karşılık verdiği oluşturmaktadır (Coyle, Jacqueline ve Kessler, 2002). Psikolojik sözleşme ve işe adanmışlık temelde Sosyal Mübadele Kuramı'na dayanmaktadır. Blau tarafından geliştirilen sosyal mübadele kuramı, bireyler arasında gerçekleşen sosyal faaliyetleri bir çeşit kaynak mübadelesi şeklinde gören oldukça eski sosyal davranış kuramlarına kadar uzanmaktadır (Bolat, Bolat ve Seymen, 2009). Dolayısıyla çalışanların psikolojik sözleşme algısının yönü ve şiddeti onların işe adanmışlıkları üzerinde etkili olacağı düşünülmektedir. Psikolojik sözleşme ve işe adanmışlık ilişkisi aynı zamanda Gouldner tarafından ileri sürülen Karşılıklılık Norm Kuramı'na da dayanmaktadır. Karşılıklılık Normu, insanların elde ettikleri yararlara karşılık olumlu davranış göstereceği temeline dayanmaktadır (Gouldner, 1960). Karşılıklılık, bireyleri bencil ve çıkarcı kalıplarından çıkararak, ortak çıkarlar ve ortak faydada toplayarak bir topluluğun üyesi yapmaktadır (Adler ve Kwon, 2002). 
Psikolojik sözleşme kavramının işe adanmışlık ile ilişkisini ortaya koyan diğer bir kuram ise V. Vroom tarafından geliştirilen Vroom'un Beklenti Kuramı'dır (Akat, Budak ve Budak, 1994). Vroom'un (1964) beklenti kuramına göre bireyin bir iş adına gayret göstermesi o iş neticesinde elde edeceği ödüle yönelik arzulama derecesi, ödülü elde edebilme ihtimali ve bu ödülün bireysel hedefleri ile olan ilişkisine bağlıdır. Bu kurama göre birey için ödüle ulaşabilme ihtimali ne kadar yüksek ve ne kadar ilgi çekici ise motivasyon da o derece yüksek olmakta ve kişi kendi kapasitesi doğrultusunda tercih yapmaktadır (Yılmaz ve Turgut, 2016). Kavramlar arasındaki ilişkiyi ortaya koyan diğer bir kuram ise Adams'ın Eşitlik Kuramı'dır. Eşitlik kuramı, Adams tarafından geliştirilerek, motivasyonla alakalı sosyal karşılaştırma kuramlarının en popüleri olarak bilinmektedir (K1lıç, 2016). Eşitlik kuramının temel bileşenleri; bir işe kişiler tarafından yapılan katkılar, çalışanların bir işe dair elde ettikleri ödüller/cezalar şeklinde ifade edilen çıktılar, çalışanlar tarafindan kendilerinin eşit/eşitsizlik durumu içerisinde oldukları yönünde algılamalarını belirleyen karşılaştırmalar, çalışanların kendi girdi ve çıktılarını diğer bireylerle kıyaslaması, eşitsizlik durumunda bireylerin göstereceği psikolojik ve davranışsal tepkileri kapsamaktadır (Bolino ve Turnley, 2008).

Psikolojik sözleşme ve işe adanmışlıkla ilgili yapılan çalışmalar çok olmakla birlikte söz konusu kavramların birbiriyle ilişkisi açısından ele alınmış çalışma sayısı oldukça azdır. Turunç ve Avcı (2015) yaptıkları çalışma neticesinde; psikolojik sözleşme kapsamında da yer alan karşılıklı yükümlülükler ve beklentiler doğrultusunda anlaşılan kurumsal desteğin, vazgeçme niyeti ile alakalı olduğunu ve vazifeden ayrılma niyetini olumsuz ve anlamlı olarak etkilediğini ortaya çıkarmışlardır. Çalışma, karşılıklı yükümlülük ve beklentilerin yerine getirilmesiyle, çalışanlarda işe adanmışlığın oluşturulabileceğine yönelik önemi ortaya koymaktadır. Rousseau (1995), Nicholson ve Johns (1985) ve Robinson (1996) çalışmalarında, psikolojik sözleşmeye uygun bütün beklentileri yerine getirilen ve psikolojik sözleşmesi eksiksiz olan çalışanların işe adanmış birer çalışan olacağı yönündeki düşünceleri, psikolojik sözleşme ile işe adanmışlık arasındaki ilişkinin varlığını ve gücünü ortaya koymaktadırlar. Ayrıca Freese ve Schalk (1996) yaptığı araştırmada, işe adanmışlık ile yakından ilişkili olan özdeşleşme ile psikolojik sözleşmenin aynı yönlü ilişkiye sahip olduklarını tespit etmişlerdir. Shore ve Barksdale (1998) ise ilişkisel sözleşmenin daha fazla duygusal bağl1lık ile alakalı olduğunu ifade etmişlerdir. Yine aynı şekilde Özler ve Ünver (2012)'in yükseköğretim kurumlarında vazife yapan akademik personelin psikolojik sözleşmelerinin işe adanmışlık ile yakından ilişkili olan iş tatmini hususundaki etkilerini ölçmeye ilişkin gerçekleştirmiş oldukları araştırma neticesinde; akademik personelin psikolojik sözleşmeye yönelik davranışlarının iş tatminlerini mühim bir düzeyde etkilediği kanaatine varılmışlardır.

Psikolojik sözleşme çalışan açısından ele alındığında örgütten beklentileri doğrultusunda çalışanın işe adanmışlık düzeyinin şekilleneceğine inanılmaktadır. Farklı araştırma tasarımlarıyla bu etkileşimin incelenmesi psikolojik sözleşme ve işe adanmışl1k ilişkisine dair literatürü güçlendirecektir. $\mathrm{Bu}$ bağlamda yukarıda ele alınan kuramsal altyapı ve gerçekleştirilen görgül araştırmalara dayanılarak psikolojik sözleşme algısı ile işe adanmışlık arasındaki ilişkiye yönelik aşağıdaki hipotezler ortaya konulmuştur.

\section{$\boldsymbol{H}_{1}$ : Psikolojik sözleşme algısı işe adanmışlı̆̆ı etkilemektedir.}

$\mathbf{H}_{1 \mathbf{a}}$ : Psikolojik sözleşmenin alt boyutu işlemsel sözleşme algısı işe adanmışlı̆̆ etkilemektedir.

$\mathbf{H}_{1 \mathrm{~b}}$ : Psikolojik sözleşmenin alt boyutu ilişkisel sözleşme algısı işe adanmışlı̆̆ etkilemektedir.

$\boldsymbol{H}_{2}$ : Psikolojik sözleşme algısı işe adanmışlı̆̆ı dinçlik boyutunu etkilemektedir.

$\mathbf{H}_{2 \mathrm{a}}$ : Psikolojik sözleşmenin alt boyutu işlemsel sözleşme algısı işe adanmışlı̆ı̆ı dinçlik boyutunu etkilemektedir.

$\mathbf{H}_{2 b}$ : Psikolojik sözleşmenin alt boyutu ilişkisel sözleşme algısı işe adanmışlığın dinçlik boyutunu etkilemektedir.

\section{$\boldsymbol{H}_{3}$ : Psikolojik sözleşme algısı işe adanmışlı̆̆ın yoğunlaşma boyutunu etkilemektedir.}

$\mathbf{H}_{3 \mathbf{a}}$ : Psikolojik sözleşmenin alt boyutu işlemsel sözleşme algısı işe adanmışlığın yoğunlaşma boyutunu etkilemektedir.

$\mathbf{H}_{\mathbf{3 b}}$ : Psikolojik sözleşmenin alt boyutu ilişkisel sözleşme algısı işe adanmışlığın yoğunlaşma boyutunu etkilemektedir. 
$\boldsymbol{H}_{4}$ : Psikolojik sözleşme algısı işe adanmışlığın adanma boyutunu etkilemektedir.

$\mathbf{H}_{4 \mathbf{a}}$ : Psikolojik sözleşmenin alt boyutu işlemsel sözleşme algısı işe adanmışlı̆̆ın adanma boyutunu etkilemektedir.

H4b: Psikolojik sözleşmenin alt boyutu ilişkisel sözleşme algısı işe adanmışlı̆ın adanma boyutunu etkilemektedir.

\section{Yöntem}

\section{Araştırmanın Modeli}

Araştırmanın temel hipotezi olan "Psikolojik sözleşme algısı işe adanmışlık düzeyini etkilemektedir." hipotezi ve alt hipotezler kapsamında oluşturulan araştırma modeli Şekil 1'de sunulmaktadir.

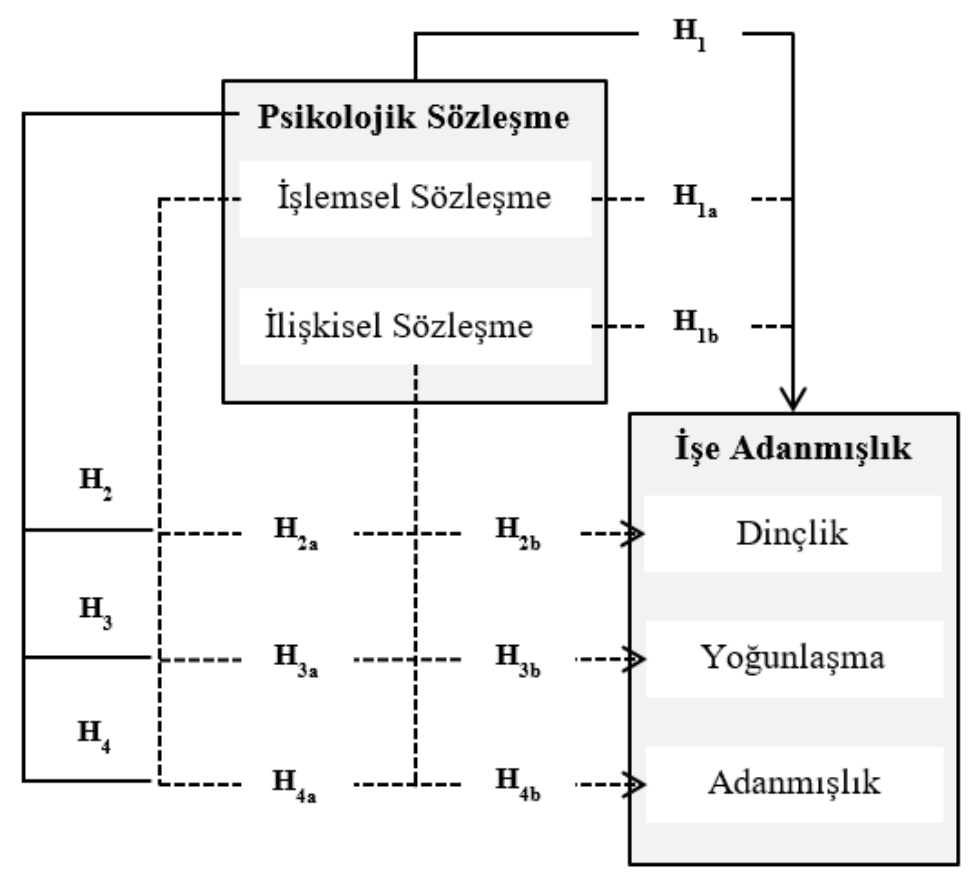

Şekil 1. Araştırmanın modeli

\section{Evren ve Örneklem}

Kastamonu Üniversitesinde gerçekleştirilen bu araştırmanın evreni 400 idari personelden oluşmaktadır. $\mathrm{Bu}$ araştırmada tesadüfi olmayan örnekleme tekniklerinden olan kolayda örnekleme tekniği uygulanmıştır. 400 kişiden oluşan bir evrenin $\alpha=0.05$ anlamlı olması ve $\pm \% 5$ hata payının hedeflenmesi durumunda araştırmaya dâhil edilmesi gereken kişi sayısının 196 olduğu ortaya çıkmaktadır (Baş, 2010; Davis ve Cosenza, 1998; Yamane, 2001). Bu kapsamda 275 anket formu katılımcılar için gönderilmiş, ancak 362 anketin geri dönüşü sağlanmıştır. Eksik ve yanlış doldurulan ve aynı zamanda güvenilirliği zedeleyici anketler çıkarıldıktan sonra evreni temsil kapasitesine sahip 250 kullanılabilir anket formu veri analizlerine dâhil edilmiştir. Araştırma örnekleminin (idari personel) $75^{\prime}$ i (\%30) kadın ve 175 'i (\%70) gibi büyük bir çoğunluğu erkektir. Erkek ve kadın personelden 161'i $(\% 64,4)$ evli ve 89'u $(\% 35,6)$ bekârdır. İdari personelin 160’1 (\%64) 25 - 36 yaş aralığındadır. Aynı zamanda personelin 62'si $(24,8)$ yöneticilik görevi olduğunu ifade ederken, 188'i $(\% 75,2)$ yöneticilik görevi olmadığını belirtmiştir. Hizmet süresi açısından personelin 31 'i $(\% 12,4) 3$ yıl ve daha az, 97'si $(\% 38,8)$ 4-9 yıl, 63'ü $(\% 25,2) 10-15$ yıl ve 59'ü $(\% 23,6) 16$ yıl ve üzerinde k1deme sahip olduğunu belirtmektedir. 


\section{Veri Toplama Araçları}

Araştırmanın verileri anket tekniği ile toplanmıştır. Araştırmada "Psikolojik Sözleşme Algısı Ölçeği” ve "İşe Adanmışlık Ölçeği" kullanılmıştır.

\section{Psikolojik Sözleşme Algısı Ölçeği}

Araştırmada, çalışanların psikolojik sözleşme algılarını ölçmek gayesiyle Millward ve Hopkins (1998) tarafından geliştirilen, Türkçe'ye Mimaroğlu (2008) tarafından uyarlanan geçerliği ve güvenirliği yapılmış "Psikolojik Sözleşme Algısı Ölçeği" kullanılmıştır. Ölçek, iki boyut onyedi ifadeden oluşmaktadır. Bu ifadelerden on tanesi işlemsel psikolojik sözleşme ve yedi tanesi ise ilişkisel psikolojik sözleşme boyutlarına aittir. Ölçekte örnek olarak; "Sadece işimin gereklerini yerine getiriyorum." ve "Bu kurumda kendimi takımın bir parçası gibi hissediyorum." ifadeleri bulunmaktadır. Ölçeğin puanlaması, 5'li Likert ölçeğine göre yapılmıştır (1= kesinlikle katılmıyorum; $5=$ kesinlikle katılıyorum). Psikolojik Sözleşme Algısı Ölçeği'nin yapısal geçerliliği test etmek gayesiyle faktör analizi, güvenirliğini test etmek için ise sosyal bilimlerde en çok tercih edilen iç tutarlılık analizi (Cronbach Alfa katsayısı) gerçekleştirilmiş (Erkuş, 2009; Özdamar, 2004) olup, değeri .794 olarak ölçülmüştür. Psikolojik Sözleşme Algısı Ölçeği’ne ilişkin faktör analizi bulguları Tablo 1'de gösterilmektedir.

Tablo 1

Psikolojik Sözleşme Algısı Ölçeğinin Faktör Analizi ve Bulguları

\begin{tabular}{lcccc}
\hline Faktörler & $\begin{array}{l}\text { Madde } \\
\text { Sayı1 }\end{array}$ & \multicolumn{1}{l}{$\begin{array}{l}\text { Fak. Yük. } \\
\text { Aralığ }\end{array}$} & $\begin{array}{l}\text { Açıklanan } \\
\text { Varyans (\%) }\end{array}$ & Özdeğer \\
\hline Psikolojik Sözleşme Algısı & 17 &, $747-, 879$ & 70,247 & \\
İşlemsel Psikolojik Sözleşme & 10 &, $818-, 879$ & 41,711 & 7,095 \\
$\quad$ İlişkisel Psikolojik Sözleşme & 7 &, $747-, 869$ & 28,556 & 4,850 \\
\hline
\end{tabular}

Kaiser-Meyer-Olkin örneklem yeterliliği değeri: ,920

Barlett küresellik testi: ki-kare $=3461,818 ; \mathrm{df}=136 ; \mathrm{p}=, 000$

Kastamonu Üniversitesi idari personelinden elde edilen veriler çerçevesinde, Psikolojik Sözleşme Ölçeği'ne temel bileşenler yöntemi ve varimax rotasyonuna göre faktör analizi yapılmıştır. Ölçeğin, KMO değeri 0,920 ve Bartlett değeri $\mathrm{p}<0,000$ olarak anlamlı çıkmıştır. Bu değerlere göre; Psikolojik Sözleşme Ölçeği'nin faktör analizine uygunluğu görülmüştür. Ölçek, toplam varyansın \%70,247'sini açıklamaktadır ve öz değeri 1'in üzerinde olan iki alt boyuttan oluşmaktadır. Faktör yüklerinin ise $.747-.879$ arasında değiştiği görülmektedir. Dolayısıyla faktör yüklerinin 0,32 veya 0,35 'ten büyük olması gerektiği fikrinden hareket ederek, ölçeğin kullanılabilir olduğunu söylemek mümkündür (Tabachnick ve Fidell, 1989).

\section{İşe Adanmışlık Ölçeği}

Araştırmada, çalışanların işe adanmışlık düzeylerini ölçmede Schaufeli ve arkadaşları (2002) tarafından geliştirilen, Türkçe'ye Turgut (2011) tarafından uyarlanan geçerliği ve güvenirliği yapılmış "İşe Adanmışlık Ölçeği - Utrecht Work Engagement Scale (UWES)" kullanılmıştır. Ölçek, üç boyut onyedi ifadeden oluşmaktadır. Bu ifadelerden altı tanesi dinçlik ve altı tanesi yoğunlaşma ve beş tanesi ise adanmışlık boyutlarına aittir. Ölçekte örnek olarak; "İşimde kendimi güçlü ve dinç hissederim." ve "Çalışırken zamanın nasıl geçtiğini anlamam." ifadeleri yer almaktadır. Ölçeğin puanlaması, 5'li Likert ölçeğine göre yapılmıştır ( $1=$ kesinlikle katılmıyorum; $5=$ kesinlikle katılıyorum). İşe Adanmışlık Ölçeği'nin yapısal geçerliliğini test etmek amacıyla faktör analizi, güvenirliğini test etmek için ise iç tutarlılık analizi (Cronbach Alfa) gerçekleştirilmiş olup, değeri .878 olarak ölçülmüştür. İşe Adanmışılı Ölçeği ile alakalı faktör analizi bulguları Tablo 2'de gösterilmektedir. 
Tablo 2

İşe Adanmışlık Ölçeğinin Faktör Analizi ve Bulguları

\begin{tabular}{|c|c|c|c|c|}
\hline Faktörler & Madde Sayısı & Fak. Yük. Aralığı & Açıklanan Varyans (\%) & Özdeğer \\
\hline İşe Adanmışlık & 17 & ,696-,876 & 70,030 & \\
\hline Dinçlik & 6 & ,696 - , 871 & 34,383 & 5,845 \\
\hline Yoğunlaşma & 6 & ,778- -810 & 20,559 & 3,495 \\
\hline Adanmışlık & 5 &, $817-, 876$ & 15,088 & 2,565 \\
\hline
\end{tabular}

Kaiser-Meyer-Olkin örneklem yeterliliği dĕ̆eri: ,883

Barlett küresellik testi: ki-kare=2701,736; $\mathrm{df}=136 ; \mathrm{p}=, 000$

Kastamonu Üniversitesi idari personelinden elde edilen veriler çerçevesinde, İşe Adanmışlık Ölçeği'ne temel bileşenler yöntemi ve varimax rotasyonuna göre faktör analizi yapılmıştır. Ölçeğin, KMO değeri 0,883 ve Bartlett değeri $\mathrm{p}<0,000$ olarak anlamlı çıkmıştır. Bu değerlere göre; İşe Adanmışlık Ölçeği'nin faktör analizine uygun olduğu görülmektedir. Ölçek, toplam varyansın \%70,030'unu açıklamaktadır ve öz değeri 1'in üzerinde olan üç alt boyuttan oluşmaktadır. Faktör yüklerinin ise .696 - .876 arasında değiştiği görülmektedir.

\section{Bulgular}

$\mathrm{Bu}$ bölümde, araştırmada yer alan değişkenler arasındaki ilişkinin şiddetini ve yönünü belirlemek amacıyla korelasyon analizi ve psikolojik sözleşme algısının işe adanmışlık üzerindeki etkisini belirlemek amacıyla ise çoklu regresyon analizi kullanılmıştır.

\section{Korelasyon Analizi}

Psikolojik sözleşme algısı ile işe adanmışlık arasındaki ilişkinin şiddetini ve yönünü belirlemek amacıyla korelasyon analizi yapılmıştır (Tablo 3).

Tablo 3

Korelasyon Analizi ve Bulgularl

\begin{tabular}{|c|c|c|c|c|c|c|c|c|}
\hline \multicolumn{2}{|c|}{ Değişkenler } & 1 & 2 & 3 & 4 & 5 & 6 & 7 \\
\hline 1 & Psikolojik Sözleşme Algısı & 1 & & & & & & \\
\hline 2 & İşlemsel Psikolojik Sözleşme &, $831^{* *}$ & 1 & & & & & \\
\hline 3 & İlişkisel Psikolojik Sözleşme &, $553^{* *}$ &, 017 & 1 & & & & \\
\hline 4 & Isşe Adanmışlık &, $355^{* *}$ &, 108 &, $480^{* *}$ & 1 & & & \\
\hline 5 & Dinçlik &, $142^{*}$ &, 065 &, $159^{*}$ &, $791^{* *}$ & 1 & & \\
\hline 6 & Yoğunlaşma &, $168^{* *}$ &, $134^{*}$ &, 084 &, $742^{* *}$ &, $359^{* *}$ & 1 & \\
\hline 7 & Adanmışlık &, $515^{* *}$ &, 003 &, $953^{* *}$ &, $504^{* *}$ &, $175^{* *}$ & ,081 & 1 \\
\hline
\end{tabular}

$* *_{\mathrm{p}}<0.01, * \mathrm{p}<0.05$ düzeyinde anlamlıdır. 
Tablo 3'teki sonuçlara göre; psikolojik sözleşme algısının işe adanmışlık düzeyiyle zayıf bir ilişki $(r=0,355)$, işe adanmışlığın alt boyutu olan dinçlik $(r=0,142)$ ve yoğunlaşma ile $(r=0,168)$ çok zayıf bir ilişkide olduğu tespit edilmiştir. Ancak psikolojik sözleşme algısı ile işe adanmışlı̆̆ın alt boyutu olan adanmışlık arasında $(r=0,515)$ orta düzeyde bir ilişki olduğu görülmektedir. Psikolojik sözleşme algısının alt boyutu olan işlemsel sözleşme algısının yalnızca işe adanmışlığın alt boyutu olan yoğunlaşma boyutu ile çok zayıf bir ilişkide olduğu görülmektedir $(r=0,134)$. Son olarak psikolojik sözleşme algısının alt boyutu olan ilişkisel sözleşme algısı ile işe adanmışlık düzeyi arasında zayıf $(\mathrm{r}=0,480)$ bir ilişki vardır. Ayrıca işe adanmışlık ölçeğinin alt boyutu olan dinçlik ile $(\mathrm{r}=0,159)$ çok zayıf bir ilişkisi varken adanmışlık boyutu arasında çok yüksek bir ilişkisinin olduğu tespit edilmiştir $(\mathrm{r}=0,953)$.

\section{Çoklu Regresyon Analizi}

Araştırma hipotezlerinin test edilmesi amacıyla çoklu regresyon analizinden faydalanılmıştır. Psikolojik sözleşme algısının işe adanmışlık üzerindeki etkisinin incelendiği regresyon analizlerine ilişkin bulgular Tablo 4, Tablo 5, Tablo 6 ve Tablo 7'de sunulmaktadır.

Tablo 4

Psikolojik Sözleşme Alglsının (İşlemsel ve İlişkisel) İşe Adanmışlı Üzerindeki Etkisini İncelemeye Yönelik Regresyon Analizi ve Bulguları

\begin{tabular}{|c|c|c|c|c|c|}
\hline \multirow[t]{2}{*}{ Model } & \multicolumn{2}{|c|}{$\begin{array}{c}\text { Standartlaştırılmamış } \\
\text { Katsayılar }\end{array}$} & $\begin{array}{l}\text { Standartlaştırılmış } \\
\text { Katsayılar }\end{array}$ & \multirow[t]{2}{*}{$\mathrm{t}$} & \multirow[t]{2}{*}{$\mathrm{p}$} \\
\hline & $\mathrm{B}$ & Std. Hata & Beta & & \\
\hline Sabit & 1,280 & 0,257 & & 4,989 & $0,000^{*}$ \\
\hline İşlemsel Sözleşme & 0,098 & 0,054 & 0,100 & 1,801 & 0,073 \\
\hline İlişkisel Sözleşme & 0,528 & 0,061 & 0,478 & 8,616 & $0,000^{*}$ \\
\hline $\mathrm{R}$ & 0,490 & & & & \\
\hline $\mathrm{R}^{2}$ & 0,240 & & & & \\
\hline Düzeltilmiş $\mathrm{R}^{2}$ & 0,234 & & & & \\
\hline Standart Hata & 0,592 & & & & \\
\hline $\mathrm{F}$ & 39,023 & & & & $0,000^{*}$ \\
\hline Durbin-Watson & 1,886 & & & & \\
\hline
\end{tabular}

Araştırmanın bağımsız değişkeni olan psikolojik sözleşme algısının (işlemsel ve ilişkisel) bağımlı değişken olan işe adanmışlık üzerindeki etkisini çoklu regresyon analizi ile test edilmiştir (Tablo 4). Psikolojik sözleşme algısı alt boyutlarıyla ilgili düzeltilmiş determinasyon katsayısı \%23,4 olarak çıkmıştır. Dolayısıyla işe adanmışlık düzeyinde yaşanan değişimin \%23,4'ü psikolojik sözleşme algısının alt boyutlarına bağlı olarak değişim göstermektedir. Modelin 39,023 F değeriyle anlamlı bir sonuç vermiş $(\mathrm{p}<0,01)$ olması kurulan modelin $\% 99$ güven düzeyinde anlamlı olduğuna işaret etmektedir. $\mathrm{Bu}$ bulguya göre $\mathrm{H}_{1}$ "Psikolojik sözleşme algısı işe adanmışlık düzeyini etkilemektedir." hipotezi desteklenmektedir. Ayrıca modelde anlamlı neticeler veren bağımsız değişkenlerden ilişkisel sözleşme boyutunun katsayısı 0,528'dir. Bu çerçevede; personelin işe adanmışlık düzeyini, ilişkisel sözleşme algısının 0,528 birim etkilediği tespit edilmiştir $(p<0,01)$. Buna göre $\mathrm{H}_{1 \mathrm{~b}}$ "Psikolojik sözleşmenin alt boyutu olan iliş̧isel sözleşme algısı işe adanmışlık düzeyini etkilemektedir." hipotezi desteklenmektedir. Ancak $\mathrm{H}_{1 \mathrm{a}}$ "Psikolojik sözleşmenin alt boyutu olan işlemsel sözleşme algısı işe adanmışlık düzeyini etkilemektedir." hipotezi desteklenmemektedir. 
Tablo 5

Psikolojik Sözleşme Algısının (İşlemsel ve İlişkisel) İşe Adanmışlı̆̆n Dinçlik Boyutuna Etkisini Incelemeye Yönelik Regresyon Analizi ve Bulguları

\begin{tabular}{llllll}
\hline \multirow{2}{*}{ Model } & \multicolumn{2}{l}{$\begin{array}{l}\text { Standartlaştırılmamış } \\
\text { Katsayılar } \\
\text { B }\end{array}$} & $\begin{array}{l}\text { Standartlaştııılmış } \\
\text { Katsayır } \\
\text { Beta }\end{array}$ & $\mathrm{t}$ & $\mathrm{p}$ \\
\hline Sabit & 1,823 & 0,448 & & 4,071 & $0,000^{*}$ \\
İşlemsel Sözleşme & 0,094 & 0,095 & 0,062 & 0,992 & 0,322 \\
İlişkisel Sözleşme & 0,270 & 0,107 & 0,158 & 2,522 & $0,012^{* *}$ \\
$\mathrm{R}$ & 0,171 & & & & \\
$\mathrm{R}^{2}$ & 0,029 & & & & \\
Düzeltilmiş $\mathrm{R}^{2}$ & 0,021 & & & & \\
Standart Hata & 1,033 & & & & \\
F & 3,718 & & & & \\
Durbin-Watson & 1,615 & & & & \\
\hline
\end{tabular}

$* \mathrm{p}<0,01, * * \mathrm{p}<0,05$

Psikolojik sözleşme algısını (işlemsel ve ilişkisel) işe adanmışlığın alt boyutu olan dinçlik boyutunu etkileyip etkilemediğini belirlemek için yapılan çoklu regresyon analizi sonuçları Tablo 5'de sunulmuştur. Psikolojik sözleşme algısı alt boyutlarıyla ilgili düzeltilmiş determinasyon katsayısı \%02,1'dir. Dolayısıyla işe adanmışlığın alt boyutu olan dinçlik boyutunda yaşanan değişimin \%02,1'i psikolojik sözleşme algısının alt boyutlarına bağlı olarak değişim göstermektedir. Bununla birlikte modelin 3,718 $\mathrm{F}$ değeriyle anlamlı bir sonuç vermiş $(\mathrm{p}<0,05)$ olması kurulan modelin $\% 95$ güven düzeyinde anlamlı olduğuna işaret etmektedir. $\mathrm{Bu}$ bulguya göre $\mathrm{H}_{2}$ "Psikolojik sözleşme algısı işe adanmışlı̆̆ın dinçlik boyutunu etkilemektedir." hipotezi desteklenmektedir. Modelde anlamlı neticeler veren bağımsız değişkenlerden ilişkisel sözleşme boyutunun katsayısı 0,270'dir. Bu çerçevede; idari personelin dinçlik düzeyini, ilişkisel sözleşme algısının 0,270 birim etkilediği belirlenmiştir $(p<0,05)$. Dolayısıyla $\mathrm{H}_{2 \mathrm{~b}}$ "Psikolojik sözleşmenin alt boyutu olan ilişkisel sözleşme algısı işe adanmışlı̆̆n dinçlik boyutunu etkilemektedir." hipotezi desteklenmektedir. Ancak $\mathrm{H}_{2 \mathrm{a}}$ "Psikolojik sözleşmenin alt boyutu olan işlemsel sözleşme algısı işe adanmışliğın dinçlik boyutunu etkilemektedir." hipotezi desteklenmemektedir.

Psikolojik sözleşme algısının (işlemsel ve ilişkisel) işe adanmışlığın alt boyutu olan yoğunlaşma boyutunu etkileyip etkilemediğini belirlemek için yapılan çoklu regresyon analizi sonuçları Tablo 6'da gösterilmektedir. Psikolojik sözleşme algısı alt boyutlarıyla alakalı düzeltilmiş determinasyon katsayısı \%01,7'dir. Başka bir deyişle işe adanmışlığın alt boyutu olan yoğunlaşma boyutunda yaşanan değişimin \%01,7'si psikolojik sözleşme algısının alt boyutlarına bağlı olarak değişim göstermektedir. Ayrıca modelin 3,136 F değeriyle anlamlı bir sonuç vermiş $(\mathrm{p}<0,05)$ olması kurulan modelin \%95 güven düzeyinde anlamlı olduğuna işaret etmektedir. Bu bulguya göre $\mathrm{H}_{3}$ "Psikolojik sözleşme algısı işe adanmışlı̆̆ın yoğunlaşma boyutunu etkilemektedir." hipotezi desteklenmektedir. Modelde anlamlı sonuçlar veren bağımsız değişkenlerden işlemsel sözleşme boyutunun katsayısı 0,189 'dur. Bu sonuç; idari personelin yoğunlaşma düzeyini, işlemsel sözleşme algısının 0,189 birim etkilediğine işaret etmektedir $(p<0,05)$. Bu bağlamda $\mathrm{H}_{3 a}$ "Psikolojik sözleşmenin alt boyutu olan işlemsel sözleşme algısı işe adanmışlı̆ğı yoğunlaşma boyutunu etkilemektedir." hipotezi desteklenmektedir. Ancak $\mathrm{H}_{3 \mathrm{~b}}$ "Psikolojik sözleşmenin alt boyutu olan ilişkisel sözleşme algısı işe adanmışlığın yoğunlaşma boyutunu etkilemektedir." hipotezi desteklenmemektedir. 
Tablo 6

Psikolojik Sözleşme Algısının (İşlemsel ve İlişkisel) İşe Adanmışlı̆̆ı Yoğunlaşma Boyutuna Etkisini Incelemeye Yönelik Regresyon Analizi ve Bulguları

\begin{tabular}{llllll}
\hline \multirow{2}{*}{ Model } & \multicolumn{2}{l}{$\begin{array}{l}\text { Standartlaştırılmamı̧ } \\
\text { Katsayılar } \\
\text { B }\end{array}$} & $\begin{array}{l}\text { Std. Hata } \\
\text { Katsayılaştırılmış } \\
\text { Beta }\end{array}$ & $\mathrm{t}$ & $\mathrm{p}$ \\
\hline Sabit & 2,492 & 0,422 & & 5,905 & $0,000^{*}$ \\
İşlemsel Sözleşme & 0,189 & 0,090 & 0,133 & 2,113 & $0,036^{* *}$ \\
İlişkisel Sözleşme & 0,132 & 0,101 & 0,082 & 1,307 & 0,192 \\
$\mathrm{R}$ & 0,157 & & & & \\
$\mathrm{R}^{2}$ & 0,025 & & & & \\
Düzeltilmiş R & 0,017 & & & & \\
Standart Hata & 0,974 & & & & $0,045^{* *}$ \\
F & 3,136 & & & & \\
Durbin-Watson & 1,912 & & & & \\
\hline
\end{tabular}

$* \mathrm{p}<0,01, * * \mathrm{p}<0,05$

Psikolojik sözleşme algısının (işlemsel ve ilişkisel) işe adanmışlığın alt boyutu olan adanmışlık boyutunu etkileyip etkilemediğini belirlemek için yapılan çoklu regresyon analizi sonuçları Tablo 7'de sunulmuştur. Psikolojik sözleşme algısı alt boyutlarıyla ilgili düzeltilmiş determinasyon katsayısı \%90,7'dir. Buna göre işe adanmışlığın alt boyutu olan adanmışlık boyutunda yaşanan değişimin \%90,7'si psikolojik sözleşme algısının alt boyutlarına bağlı olarak değiş̧im göstermektedir. Bununla birlikte Modelin 216,729 F değeriyle anlamlı bir sonuç vermiş $(p<0,01)$ olması kurulan modelin \%99 güven düzeyinde anlamlı olduğuna işaret etmektedir. Bu bulguya göre $\mathrm{H}_{4}$ "Psikolojik sözleşme algısı işe adanmışlığın adanma boyutunu etkilemektedir." hipotezi desteklenmektedir. Modelde anlamlı neticeler veren bağımsız değişkenlerden ilişkisel sözleşme boyutunun katsayısı 1,317'dir. Buna göre; idari personelin kendilerini kuruma adama düzeylerini, ilişkisel sözleşme algısının 1,317 birim etkilediği söylenebilir $(\mathrm{p}<0,01)$. Bu çerçevede $\mathrm{H}_{4 \mathrm{~b}}$ "Psikolojik sözleşmenin alt boyutu olan ilişkisel sözleşme algisı işe adanmışığın adanma boyutunu etkilemektedir." hipotezi desteklenmektedir. Ancak $\mathrm{H}_{4 a}$ "Psikolojik sözleşmenin alt boyutu olan işlemsel sözleşme algısı işe adanmışlı̆̆ın adanma boyutunu etkilemektedir." hipotezi desteklenmemektedir.

Tablo 7

Psikolojik Sözleşme Algısı Alt Boyutlarının İşe Adanmışlığın Adanmışlık Boyutuna Etkisini İncelemeye Yönelik Regresyon Analizi ve Bulgulart

\begin{tabular}{llllll}
\hline \multirow{2}{*}{ Model } & \multicolumn{2}{l}{$\begin{array}{l}\text { Standartlaştırılmamış } \\
\text { Katsayır } \\
\text { B }\end{array}$} & $\begin{array}{l}\text { Standartlaştırıllmış } \\
\text { Katsayılar } \\
\text { Beta }\end{array}$ & $\mathrm{t}$ & $\mathrm{p}$ \\
\hline Sabit & $-0,823$ & 0,112 & & $-7,358$ & $0,000^{*}$ \\
İşlemsel Sözleşme & $-0,016$ & 0,024 & $-0,013$ & $-0,690$ & 0,491 \\
İlişkisel Sözleşme & 1,317 & 0,027 & 0,953 & 9,330 & $0,000^{*}$ \\
$\mathrm{R}$ & 0,953 & & & & \\
$\mathrm{R}^{2}$ & 0,908 & & & & \\
Düzeltilmiş $\mathrm{R}^{2}$ & 0,907 & & & & \\
Standart Hata & 0,258 & & & & $0,000^{*}$ \\
F & 216,729 & & & & \\
Durbin-Watson & 1,856 & & & & \\
\hline
\end{tabular}

$* \mathrm{p}<0,01$ 


\section{Sonuç, Tartışma ve Öneriler}

Örgütler, insanlar gibi yaşayan karmaşık yapılar olup çalışanları ile sürekli bir etkileşim içerisindedirler. $\mathrm{Bu}$ ilişkinin sürdürülebilir olması, yöneticilerin çalışanlarla kurdukları psikolojik sözleşmenin varlığına bağlıdır. Kurumlarda personelin psikolojik sözleşme algısının düşük veya olumsuz olması, verimliliği etkileyecek işyeri davranışlarına neden olduğu çeşitli çalışmalarda ortaya konulmuştur (Bies ve Tyler, 1993; Hussain, Muahammad, Ahmed ve Humyaun, 2011; Kaufmann ve Stern, 1988; Kickul, 2001; Morrison ve Robinson, 1997; Robinson, 1996). Bu açıdan çalışanların gelişimine katkı sağlamak, terfi ettirme gibi imkânlar sağlanarak, kuruma bağlılıkları arttırılarak ve tatminleri sağlanarak sınırları belli olmayan psikolojik ilişkilerin güçlendirilmesi kurumlar için bir gereklilik olarak kabul edilebilir (Yardan ve Dikmetaş, 2013). Psikolojik sözleşme kavramı, örgüt içinde meydana gelen çatışmaları, işe devamsızlıkları, personel devir hızını ve iş tatminsizliğini ortadan kaldıran işe adanmışlık açısından da büyük önem taşımaktadır (Demiral, 2008). Örgütlerin çalışanları ile kuracakları etkileşim Sosyal Mübadele Kuramı ve Karşı1ıklılık Norm Kuramı temelinde örgüt-çalışan davranışlarının birbirini şekillendirmesine neden olacaktır. Çalışan açısından bu etkileşim ele alındığında örgütten beklentileri karşılanan çalışanın işe adanmışlık eğiliminde olacağı düşünülmektedir. Nitekim Vroom'un Beklenti Kuramı ve Adams'ın Eşitlik Kuramı çalışanların örgütten beklentilerini açıklar niteliktedir. Teorik temeli ortaya konulan bu etkileşime görgül dayanak oluşturmak için çalışanların farklı örgüt yapılarında şekillenen beklentilerinin psikolojik sözleşme algısı bağlamında işe adanmışlıklarını nasıl etkilediğinin incelenmesi yararlı olacaktır. Bu bağlamda Kastamonu Üniversitesi'nde çalışan idari personel üzerinde bir alan araştırması gerçekleştirilmiştir.

Araştırmada psikolojik sözleşme algısının idari personelin işe adanmışlık düzeyini etkilediği çoklu regresyon analizi ile tespit edilmiştir. Aynı zamanda psikolojik sözleşme algısı alt boyutlarının (işlemsel ve ilişkisel) işe adanmışlık düzeyindeki etkisinde sadece ilişkisel sözleşme algısının etkilediği tespit edilmiştir. Psikolojik sözleşme algısı ve alt boyutlarının, işe adanmışlığın alt boyutlarını etkileyip etkilemediği de çoklu regresyon analizi ile test edilmiştir. Bulgular; psikolojik sözleşme algısının işe adanmışlığın tüm boyutlarını (dinçlik, yoğunlaşma ve adanma) etkilediğini göstermektedir. Ayrıca idari personelin işe adanmışlık boyutlarından dinçlik ve adanmışlık boyutlarını ilişkisel sözleşme algısının, yoğunlaşma boyutunu ise işlemsel sözleşme algısının etkilediği ortaya çıkmaktadır. Araştırmadan elde edilen bulgular göstermektedir ki idari personelin, çalışmaları sonucu kurumdan istediklerini alamamaları veya kendilerine vaat edilenlerin yapılmadığını düşünmeleri kuruma karşı olumsuz tavır sergilemelerini doğuracaktır. Bunun sonucunda, kuruma adanmanın aksine ayrılmaların olacağı ve yaşanan olumsuzlukların diğer paydaşları da etkileyeceği söylenebilir. Özel sektör işletmelerinde olduğu gibi kamu kurumları da belirli bir düzen içerisinde çeşitli amaçları gerçekleştirmek üzere kurulan sosyal yapılardır. Kurumsal yapının etkin bir biçimde çalışmasında ana odak noktası insan kaynağıdır. İnsan kaynağının kuruma karşı göstermiş olduğu tutum ve davranışlar kurumsal amaçlara ulaşmada kilit bir role sahiptir. $\mathrm{Bu}$ nedenle kurumda katılımcı bir yönetim anlayışının benimsenmesi, idari personele verilen sözlerin ve taahhütlerin yerine getirilmesi, yöneticilerin personele karşı adil ve dürüst olmaları personeli psikolojik olarak rahatlatacak ve kurumlarına güven duymalarını arttırmak yoluyla kuruma adanmışlık düzeylerini arttıracaktır.

Bu çerçevede, Kastamonu Üniversitesi özelinde tüm üniversiteler ve/veya kurumlar en değerli kaynağı olan insan kaynağını daha çağdaş yönetim anlayışıyla yönetmelidir. Üniversitelerde çalışan eski ve yeni idari personelin kuruma bağlılı̆̆ını sağlamak için politikalar geliştirilmelidir. Katılımcı yönetim anlayışının uygulandığı bir kurum kültürü oluşturulmalıdır. Üniversitelerin, idari personelin gözündeki kurumsal imajını ve itibarını belirlemek için belirli aralıklarla ölçümler yapmalıdır. Yapılan ölçümler sonucunda gerekli düzenlemeler yapılmalıdır. İdari personelin verimli çalışabilmesi için güvene dayalı bir ilişkinin kurulması ve etkin kariyer planlamalarının yapılması kuruma adanmanın sağlanması açısından büyük önem taşımaktadır. Üniversitelerin, öğrenen örgüt olabilmesi için idari personeli sürekli öğrenme ve geliştirmeye yöneltecek politikalar geliştirmesi de gerekmektedir. Kastamonu Üniversitesi özelinde gerçekleştirilen bu çalışmanın Türkiye'deki diğer üniversitelerde karşılaştırmalı olarak yapılabilir. Söz konusu çalışmaların, önemli birer kurum olan üniversitelerdeki idari personeller için yapılacak iyileştirmeler açısından rehber görevi görebileceği düşünülmektedir. 
Açıklamalar: $\mathrm{Bu}$ çalışma, ikinci yazarın birinci yazar danışmanlığında hazırladığı yüksek lisans tezinden üretilmiştir.

\section{Kaynaklar}

Adler, P. S. and Kwon, S. (2002). Social capital: Prospects for a new concept. Academy of Management Review, 27(1), 17-40.

Akat, İ., Budak, G. ve Budak, G. (1994). İşletme yönetimi. İstanbul: Beta Yayınları.

Anderson, N. and Schalk, R. (1998). The psychological contract in retrospect and prospect. Journal of Organizational Behavior, (19), 637-647.

Antonison, M. (2010). Evaluation of work engagement as a measure of psychological well-being from work motivation. The University of Alabama in Huntsville, Hunstville-Alabama.

Aselage, J. and Eisenberger, R. (2003). Perceived organizational support and psychological contracts: A theoretical integration. Journal of Organizational Behavior, 24, 491-509.

Bakker, A. B. (2011). An evidence-based model of work engagement. Current Directions in Psychological Science, 20(4), 265-269.

Bal, E. A. (2008). Self-efficacy, contextual factors and well-being: The impact of work engagement. Doktora tezi. Marmara Üniversitesi Sosyal Bilimler Enstitüsü, İstanbul.

Baş, T. (2010). Anket. Ankara: Seçkin Yayınları.

Bies, R. J. and Tyler, T. R. (1993). The "litigation mentality" in organizations: A test of alternative psychological explanations. Organization Science, 4(3), 352-366.

Bolat, O. İ., Bolat, T. ve Seymen, O. A. (2009). Güçlendirici lider davranışlar ve örgütsel vatandaşlık davranışı arasındaki ilişkinin sosyal mübadele kuramından hareketle incelenmesi. Balıkesir Üniversitesi Sosyal Bilimler Enstitüsü Dergisi, 12(21), 251-239.

Bolino, C. M. and Turnley, H. W. (2008). Old faces, new places: Equity theory in cross-cultural contexts. Journal of Organization Behavior, 29(1), 29-50.

Bostanc1, H. ve Ekiyor, A. (2015) Çalışanların işe adanmasının örgüt içi girișimciliğe etkisinin incelenmesi: Sağlık sektöründe bir uygulama. Uluslararası Sağllk Yönetimi ve Stratejileri Araştırma Dergisi, 1(1), 37-51.

Büyükyılmaz, O. ve Çakmak, A. F. (2014). İlişkisel ve işlemsel psikolojik sözleşmede algılanan ihlalin işten ayrılma niyeti ve algılanan örgütsel destek üzerindeki etkisi. Ege Akademik Bakış, 14(4), 583-596.

Catsouphes, M. P. and Costa, C. M. (2009). Engaging the $21^{\text {st }}$ century multi-generational workforce, finding from the age and generations study. The Sloan Center on Aging Work at Boston College.

Chughtai, A. A. and Buckley, F. (2008). Work engagement and its relationship with state and trait trust: A conceptual analysis. Journal of Behavioral and Applied Management, 10(1), 47-71.

Cihangiroğlu, N. ve Şahin, B. (2010). Organizasyonlarda önemli bir fenomen: Psikolojik sözleşme. ZKÜ Sosyal Bilimler Dergisi, 6(11), 1-16. 
Coyle, S., Jacqueline, A. M. and Kessler, I. (2002). Exploring reciprocity through the lens of the psychological contract: Employee and employer perspectives. European Journal of Work and Organizational Psychology, 11(1), 69-86.

Conway, N. and Briner, R. B. (2005). Understanding psychological contracts at work: a critical evaluation of theory and research. New York: Oxford University Press.

Davis, D. and Cosenza, R. M. (1998). Business research for decision making. Boston: Pws-Kent Publishing Company.

Deese, M. N. (2009). Testing an extention of the job demands-resources model: The addition of personal resources as mediators to the resources engagement relationship. Master Thesis. Graduate School of Clemson University.

Demiral, Ö. (2008). Örgütsel bağglllı̆gn sağlanmasında personel güçlendirme ve psikolojik sözleşmenin etkisine ilişkin bir araştırma. Yüksek Lisans Tezi. Niğde Üniversitesi Sosyal Bilimler Enstitüsü, Niğde.

Ertürk, E. (2014). Sosyal mübadele teorisi bağlamında güç mesafesi ve örgütsel adalet algılamalarının örgütsel vatandaşlık davranışı üzerindeki etkisi. Doktora tezi. Selçuk Üniversitesi Sosyal Bilimler Enstitüsü, Konya.

Erkuş, A. (2009). Davranış bilimleri için bilimsel araştırma süreci. Ankara: Seçkin Yayıncılık.

Freese, C. and Schalk, R. (1996). Implications of differences in psychological contracts for human resource management, European Journal of Work and Organizational Psychology, 5(4), 501509.

Gafa, İ. ve Dikmenli, Y. (2019). Sınıf öğretmenlerinin iş doyumu ve iş yaşamındaki yalnızlık düzeylerinin incelenmesi. Ahi Evran Üniversitesi Sosyal Bilimler Enstitüsü Dergisi, 5(1), 131150.

Goffman, E. (1959). The presentation of self in everyday life. New York: Doubleday Garden City.

Gouldner, A. W. (1960). The norm of reciprocity: A preliminary statement. American Sociological Review, 25, 161-178.

Gonzalez-Roma, V., Schaufeli, W. B., Bakker, A. B. and Lloret, S. (2006). Burnout and work engagement: Independent factors or opposite poles? Journal of Vocational Behavior, 68, 165174.

Guest, D. E. (2004). The psychology of the employment relationship: An analysis based on the psychological contract. Applied Psychology: An International Review, 53(4), 541-555.

Hussain, M. F., Muahammad, F. Y., Ahmed, N. and Humyaun, A. (2011). Psychological contract breach and work place deviance: Moderating role of relational contract. Interdisciplinary Journal of Contemporary Research in Business, 3(1), 574-586.

Kahn, W. (1990). Psychological conditions of personal engagement and disengagement at work. Academy of Management Journal, 33, 692-724.

Kanten, P. (2012). Iş̧görenlerde işe adanmanın ve proaktif davranışların oluşumunda örgütsel güven ile örgütsel özdeşleşmenin rolü. Yüksek lisans tezi. Süleyman Demirel Üniversitesi Sosyal Bilimler Enstitüsü, Isparta. 
Kaufmann, P. J. and Stern, W. L. (1988). Relational exchange norms, perceptions of unfairness, and retained hostility in commercial litigation. Journal of Conflict Resolution, 32(3), 534-552.

Kılıç, D. B. Ç. (2016). Adams'ın eşitlik teorisi bağlamında müzik öğretmenlerinin iş tatminini belirlemeye yönelik bir araştırma. Balıkesir Üniversitesi Sosyal Bilimler Enstitüsü Dergisi, 19(36), 193-235.

Kickul, J. (2001). When organizations break their promises: Employee reactions to unfair processes and treatment. Journal of Business Ethics, 29(4), 289-307.

Levinson, H., Price, C. R., Munden, K, J., Mandl, H. J. and Solley, C. M. (1962). Men, management and mental health. Cambridge: Harvard University Press.

MacNeil, I. R. (1985). Relational contract: What we do and do not know. Wisconsin Law Review, 483525 .

Maslach, C., Schaufeli, W. B. and Leiter, M. P. (2001). Job burnout. Annual Review of Psychology, $52,397-422$.

May, D. R., Gilson, R. L. and Harter, L. M. (2004). The psychological conditions of meaningfulness, safety and availability and the engagement of the human spirit at work. Journal of Occupational and Organizational Psychology, (77), 11-37.

Millward, L. J. and Hopkins, L. J. (1998). Psychological contracts, organizational and job commitment. Journal of Applied Social Psychology, 28(16), 1530-1556.

Mimaroğlu, H. (2008). Psikolojik sözleşmenin personelin tutum ve davranışlarına etkileri: Tıbbi satış temsilcileri üzerinde bir araştırma. Doktora tezi, Çukurova Üniversitesi Sosyal Bilimler Enstitüsü, Adana.

Morrison, E. W. and Robinson, S. L. (1997). When employees feel betrayed: A model of how psychological contract violation develops. Academy of Management Review, 22(1), 226-256.

Nicholson, N. and Johns, G. (1985). The absence culture and the psychological contract: Who's incontrol of absence? Academy of Management Review, 10,397-407.

Öner, Z. H. (2007). The mediating effect of organizational justice: moderating roles of sense of coherence and job complexity on the relationship between servant leadership, and work engagement. Yüksek lisans tezi. Marmara Üniversitesi Sosyal Bilimler Enstitüsü, İstanbul.

Özdamar, K. (2004). Paket programlar ile istatistiksel veri analizi-I. Eskişehir: Kaan Kitabevi.

Özler, E. ve Ünver, E. (2012). Psikolojik sözleşmenin iş tatmini üzerindeki etkisini belirlemeye yönelik bir araştırma. Süleyman Demirel Üniversitesi İktisadi ve İdari Bilimler Fakültesi Dergisi, 17(2), 325-351.

Özyılmaz, A. ve Süner, Z. (2015). İşe adanmışlı̆̆ın işyeri tutumlarına etkisi: Hatay’daki 9 işletmede yapılan ampirik araştırmanın sonuçları. Eskişehir Osmangazi Üniversitesi İktisadi ve İdari Bilimler Fakültesi Dergisi, 10(3), 143-164.

Purvis, L. J. and Cropley, M. (2003). The psychological contracts of National Health Service Nurses. Journal of Nursing Management, 11, 107-120.

Rich, B. L. (2006). Job engagement: construct validation and relationships with job satisfaction, job involvement, and intrinsic motivation. Doktoral dissertation. University of Florida. 
Roberts, D. and Davenport, T. O. (2002). Job engagement: Why it's important and how to improve it. Wiley Periodicals, Inc.

Robinson, S. L. (1996). Trust and breach of the psychological contract. Administrative Science Quarterly, 41(4), 574-599.

Rousseau, D. M. (1989). Psychological and implied contracts in organizations. Employee Responsibilities and Rights Journal, 2(2), 121-139.

Rousseau, D. M. (1995). Psychological contracts in organizations; understanding written \& unwritten agreements. California: Thousand Oaks, Sage Publications Inc.

Rousseau, D. M. and Wade-Benzoni, K. A. (1994). Linking strategy and human resource practices: How employee and customer contracts are created. Human Resource Management, 33(3), 463-489.

Schaufeli, W. B., Salanova, M., Gonzalez-Roma, V. and Bakker, A.B. (2002). The measurement of engagement and burnout: A two sample confirmatory factor analytic approach. Journal of Happiness Studies, 3, 71-92.

Schaufeli, W. B. and Bakker, A. B. (2004). UWES utrecht work engagement scale. Occupational health psychology unit, Preliminary Manual, Utrecht University.

Shore, L. M. and Tetrick, L. E. (1994). The psychological contract as an explanatory framework in the employment relationship. in Cooper, C. L. and Rousseau, D. M. (Eds.), Trends in Organizational Behavior (p. 91-109). Chichester, John Wiley \& Sons Ltd.

Shore, L. M. and Barksdale, K. (1998). Examining degree of balance and level of obligation in the employmentrelationship: A social exchange approach. Journal of Organizational Behavior, 19, 731-744.

Shraga, O. and Shiom, A. (2009). The construct validity of vigor and its antecedents: A qualitative study. Human Relations, 62(2), 271-291.

Tabachnick, B. G. and Fidel, L. S. (2013). Using multivariate statistics. USA: Pearson Education Limited.

Tarakcı, H. ve Akın, A. (2017). Psikolojik sözleşme ihlali ve örgütsel sinizm: Çorum ili örneği. Uluslararası Sosyal Araştırmalar Dergisi, 10(52), 1222-1230.

Terlemez, A. G. (2012). İşveren markasının, işe adanmışlık ve işten ayrllma niyeti ile iliş̧kisinde örgütsel çekiciliğin rolü: Türk Hava Yolları örneği. Yüksek lisans tezi, Genelkurmay Başkanlığı Harp Akademileri Komutanlığı Stratejik Araştırmalar Enstitü Müdürlüğü, İstanbul.

Topçu, M. K. (2015). Çalışanların kişilik özelliklerinin örgütsel özdeşleşme ve işten ayrılma niyeti üzerine etkisinde psikolojik sözleşme algısının rolü. Doktora tezi, Kara Harp Okulu Savunma Bilimleri Enstitüsü, Ankara.

Turgut, T. (2011). Çalışmaya tutkunluk: İş yükü, esnek çalışma saatleri, yönetici desteği ve iş-aile çatışması ile ilişkileri. Atatürk Üniversitesi İktisadi ve İdari Bilimler Dergisi, 25(3-4), 155179. 
Turnley, W. H. and Feldman, D. C. (2000). Re-examining the effects of psychological contract violations: Unmet expectations and job dissatisfaction as mediators. Journal of Organizational Behavior, 21(1), 25-42.

Turunç, Ö. ve Avcı, U. (2015). Algılanan örgütsel destek ve lider-üye etkileşiminin işten ayrılma niyeti üzerindeki etkisi: İşs stresinin aracılık rolü. Seyahat ve Otel Işletmeciliği Dergisi/Journal of Travel and Hospitality Management, 12(1), 43-63.

Tuzlukaya, Ş. ve Kırkbeşoğlu, E. (2015). Sigortacılık sektöründe örgütsel küçülmenin ardından ortaya çıkan güven bunalımı ve psikolojik sözleşme boyutlarına etkisi. Uluslararası Sosyal Araştırmalar Dergisi, 8(38), 969-979.

Üçok, D. ve Torun, A. (2014). Tükenmişliği etkileyen olumsuz tutum ve beklentiler: Sinik tutum ve psikolojik sözleşme ihlali algısı üzerine bir araştırma. Atatürk Üniversitesi İktisadi ve İdari Bilimler Dergisi, 28(1), 231-250.

Vroom, V. H. (1964). Work and motivation. New York: John Wiley \& Sons.

Yakın, M. and Erdil, O. (2012). Relationships between self-efficacy and work engagement and the effect on job satisfaction: A survey on certified public accountants. SciVerse Science Direct, (58), 370-378.

Yamane, T. (2001). Temel örnekleme yöntemleri, A. Esin, M. A. Bakır, C. Aydın ve E. Gürbüzsel (Çev.). İstanbul: Literatur Yayıncılık.

Yardan, D. E. ve Dikmetaş, H. (2013). Hastane çalışanlarının sosyotropi-otonomi kişilik özellikleri ile psikolojik sözleşme algılamaları. Gaziantep University Journal of Social Sciences, 12(1), 134145 .

Yavan, Ö. (2016). Örgütsel davranış düzleminde adanmışlık. Pamukkale Üniversitesi Sosyal Bilimler Enstitüsü Dergisi, (25), 278-296.

Yener, S. (2019). Kadın çalışanların cinsiyet rol stresi ve işe adanmışlıkları arasındaki ilişkide yaşam kalitesinin düzenleyici rolü. İsletme Fakültesi Dergisi, 20(1), 1-27.

Yener, S. ve Demirtaş, Ö. (2018). Kadın çalışanların toplumsal cinsiyet algıları ve işe adanmışlıkları arasındaki ilişki. Hitit Üniversitesi Sosyal Bilimler Enstitüsü Dergisi, 11(3), 2137-2151.

Y1lmaz, B. ve Turgut, E. (2016). Askeri ve sivil yükseköğretim kurumlarında verilen genel muhasebe eğitiminin motivasyon teorileri açısından karşılaştırmalı analizi. Uluslararası Sosyal Araştırmalar Dergisi, 9(43), 2297-2305. 


\section{Extended Abstract}

\section{Introduction}

Nowadays, formal agreements that establish the qualification and the quality of relationships which regulate the responsibilities of the parties which is developed by corporations and employees are inadequate. Because, in addition to the legal and in-house written regulations where they are employed, employees may have some expectations within themselves and often do not express them. Meeting these expectations can lead to the continuation of a trust-based relationship between the employee and the organization and the dedication of the employee to the organization. However, failure to meet mutual expectations reduces the trust in the organization and may hinder employees' commitment to the organization.

For reasons such as globalization, technological developments and intense competition, corporations try to understand employees' behaviors and increase their job satisfaction and organizational commitment in order to increase the performance of their employees. In this new process and due to the organizational changes, various concepts have emerged that regulate working relations and serve as a tool for the changes that have occurred. Psychological contract perception and work engegament have become important in both the private sector and public institutions. In order to increase employee satisfaction and loyalty to their organizations, institutions have started to focus on psychological contracting practices that prepare the ground for the employee's dedication to the organization and the establish of a trust based relationship with their employees.

The focus of this research is the level of work engagement, which is the result of the psychological contract perception. In this context, the relationship between psychological contract and commitment level is investigated. In this regard, the aim of the study is to determine the effect of the psychological contract perception on the commitment levels of the administrative staff in Kastamonu University. The main contribution of this study carried out at Kastamonu University is to enrich the literature by considering the concepts of psychological contracting and work engagement as a holistic model, which is important in public institutions as well as in private sector enterprises in our country. The second contribution is to reveal the status of administrative staff in universities that are striving towards becoming a learning organization in the information age.

\section{Method}

The population of this research carried out at Kastamonu University consists of 400 administrative staff. In this study, the non-random sampling technique, which is one of the nonprobability sampling techniques, was applied. 275 survey forms were submitted for the participants, but 262 were returned. 250 available survey forms with the capacity to represent the universe are included in the data analysis after incomplete and incorrectly filled out surveys that are also damaging to reliability.

In the study, "Psychological Contract Perception Scale", which was developed by Millward and Hopkins (1998) and adapted to Turkish by Mimaroglu (2008), was used to measure the psychological contract perceptions of employees. The scale consists of seventeen expressions of two dimensions. Ten of these expressions belong to the transactional psychological contract and the other seven belong to the relational psychological contract dimensions. "Utrecht Work Engagement Scale (UWES)", which was developed by Schaufeli et al (2002) and adapted to Turkish by Turgut (2011), was used to measure the level of work engagement. The scale consists of Seventeen expressions of three dimensions. Six of these expressions belong to vigor and six to absorption and five to dedication dimensions. Factor analyses were performed on both scales and structure validity was achieved with the original version. 


\section{Results, Discussion and Recommendations}

Correlation analysis was used to determine the severity and direction of the relationship between the variables involved in the study, and multiple regression analysis was used to determine the effect of psychological contract perception on work engagement. According to the findings of the correlation analysis, a weak relationship between the psychological contract perception and the level of dedication $\mathrm{t}(\mathrm{r}=0,355)$ and also a very weak relationship have been found between the vigor $(\mathrm{r}=0,142)$ which is the sub-dimension of work engagement and the absorption $(\mathrm{r}=0,168)$. However, there appears to be a moderate relationship between psychological contract perception and dedication $(\mathrm{r}=0,515)$, which is the sub-dimension of work engagement.

Multiple regression analysis was used to test the main hypothesis of the study structured as "psychological contract perception affects the level of work engagement". According to research findings, the multiple regression model is significant $(\mathrm{F}=39,023 ; \mathrm{p}<0.01)$ and $26.4 \%$ of the change in psychological contract perception in the work engagement variable (Adj. $\mathrm{R}^{2}=, 234$ ) appears to explain. It also appears that "relational contract" dimension $(\beta=, 478, p<0.01)$ of psychological contract perception has a positive and meaningful effect on work engagement. According to these findings, the main hypothesis of the research is supported.

In the study, it was determined by multiple regression analysis that psychological contract perception affects the level of work engagement of administrative personnel. Also, it was found that only the relational contract perception affected the psychological contract perception sub-dimensions (transactional and relational) at the level of work engagement. If the perception of psychological contract and its sub-dimensions affect the sub-dimensions of work engagement has also been tested by multiple regression analysis. The findings show that psychological contract perception affects all dimensions of work engagement (vigor, absorption, and dedication). In addition, it is revealed that the dimensions of the dedication of the administrative personnel to the work are influenced by the perception of relational contract and the concentration dimension by the perception of the transactional contract. 